\title{
Discussion on Diversified Investment and Financing Countermeasures of Private Education
}

\author{
Shuaihong Wang \\ Xi’an International University, Shaanxi, Xi'an, China, 710077
}

Keywords: Diversified Investment and Financing, Private Education, Usage of Funds, Discussion on Countermeasures.

\begin{abstract}
In the new environment, how to clearly understand the shortcomings of the private colleges during the process of their development, and how to find the right direction of their own development under the background of the education reformation, these have become the key factors that influence the development of private colleges. To private colleges, financial issue is the key factor which influences their development. During the many years development of private education, financial issue makes the managers of the colleges feel nervous all the time, if a college is lack of funds or faces the risk of financing, these issues will block the development of the college; and if these problems happen, it will bring a lot of problems to the college, such as quality of education is getting worse, lack of all some kinds of resources, etc. At present, because of some realistic reasons, not only the ways of the colleges' financing are limited, but also it is very difficult to finance enough funds, there often are many problems on investment and financing of private colleges, these greatly blocks the development of the private colleges. Start from the present situation of the private colleges' investment and financing, the writer of this thesis brings out some simple opinion in order to promote the sustainable development of private colleges.

The main way of financing of many domestic private colleges is governmental and national support, because of the long-term support, most of the private colleges neglect the other financing ways so that their ways of financing become limited, and it is hard to financing enough money as well. As the progress of recent educational reformation and the development of private colleges, the publics call for the higher teaching quality to private colleges, and the private colleges should pay more attention to increasing their financing ways in order to solve the problems of funds and make progress on their own development.
\end{abstract}

\section{Current problems of private colleges' investment and financing.}

Although the main way of financing of the most domestic private colleges in China is governmental support, but there still is a certain distance between the funds that are invested to education in China and the average level of that abroad , and the investment of education still need to be improved. So, during the development of colleges, lack of funds and governmental financial support become the common phenomena; although "education strengthens national power" is advocated in China, but the real useful effects of education reform need to be improved further more. What's more, because of the total amount of basic educational unit in China is huge, education resources are allotted to each unit unfairly, and educational task is heavy, these cause lots of colleges are lack of funds. The huge mount of basic educational unit in China leads to the financial burden of the government becomes heavier and heavier, and this is the main reason that colleges feel difficult to invest and finance funds ${ }^{[1]}$.

Most of the schools in China are used to rely on the government financial support, but this makes lots of private colleges in China lose their enthusiasms of development of their own and rely on political support all the time, and then, they become weak on undertaking risk; when they are lack of funds, they can not solve these financial problems well, but only can wait the financial support from the government with a mentality of dependence ${ }^{[2]}$. These make lots of private colleges in China feel difficult on financing funds for fulfilling the current demands of their own development. 
At present, in common Chinese rural family, a college student spends 50\% of the annual income of his or her family, this proportion in common urban family is $20 \%$, so, it is a very heavy load to a common family on paying for the tuition of a college student in China. However, the proportion in the developed countries is about $10 \%-13 \%{ }^{[3]}$, this kind of great difference shows the deficiency of domestic education system and the reasonable tuitions of many private colleges. The hug difference of tuition makes the private college face lots of obstacles on investment and financing.

Because of the strategy of "education strengthens national power" and some political supports, lots of commercial banks have taken part in educational field, and have invested a certain mount of funds to private colleges so as to provide the financial supports to the colleges. To combine the capitals of the bank with the colleges is an important way of domestic educational reformation, and an important step of promoting the development of education as well. Although this cooperative model that ties the colleges and banks has been proposed for a long time, but there still are lots of obstacles of its implement. When the colleges pay back the loans, colleges have no enough funds because the main ways of the incomes of the colleges are tuitions, fees, and financial allocations, but these have almost been spent during the daily educational activities. Moreover, according the credit rules of the banks, educational assets can not be mortgaged and the colleges also can not be the bondsman for loaning funds, therefore, it is quite difficult to loan funds to the colleges ${ }^{[4]}$.

The incomes from the colleges' industries are limited. In general, the benefits of college run enterprises in China are sizable; it provides strong financial support for the construction of colleges. But nationwide, sale income of colleges' technology enterprises only holds $2.3 \%$ of the income that comes form the total domestic high-tech enterprises, its total size is still small. Undoubtedly, to the large mount of funds that colleges need badly imminently, these funds are very little. Therefore, although the total incomes of colleges are increasing year by year, but the incomes of the colleges are still limited because of the colleges' regular incomes become less and less, which are difficult to meet the needs of the rapid increasing demands of funds for colleges' development ${ }^{[5]}$.

\section{Diversified investing and financing countermeasures of private education.}

According the relevant materials, we could find that the private colleges hold the $5 \%$ in the whole GDP of China, compared with the average level aboard that is $14 \%$, this datum of China lags behind a lot. At the some time, the total amount of domestic savings have been rising, lots of private capitals are idle. In order to optimize the usage of capitals and reallocate the resources, the colleges could carry out the reformation of property rights, let the private capital enter into the system, and let the private education in China walk on the path of the industry group, then organize a public offering for raising enough funds which could promote the development of the colleges.

(1)To issue the higher education bonds which property are national debts. In order to support the basic industry of national economy, China has issued the relevant national bonds many times when the governmental financial situation is bad. To support the development of the higher education, government could also use this method. It is feasible that the Ministry of Education issues the special bonds publicly for supporting the higher education ${ }^{[6]}$.

(2)To issue the higher education bonds which property are enterprise bonds. The higher education bond which property is enterprise bond means a kind of special bond which is issued to the publics by a college; it is similar with the enterprise bond.

Trust and Investment Company as a non-bank financial intermediary, its basic function is "manage the properties for the costumes", it could increase the ways of financial business, expand the range of financial activities, and do some business that can not be dealt with in banks. Colleges could take the best of trust for conducting financial transactions. At present, colleges in China have many kinds of foundations, such as non profit foundation which is donated by the publics, scientific research foundation and so on. But how to operate these foundations is a question, especially how to use some kinds of the huge educational fees for investing also is a question. Therefore, colleges could make these funds add value by the professional techniques of the trust and investment companies $^{[7]}$.

Private colleges need to pay attention to the three-side cooperation of college, enterprise and 
government, and combine teaching, researching and producing together. Colleges should seek for the cooperation with the relevant enterprises which can invest to the school. To seek the financial aid from the enterprise is the important way for raising funds of the college; it is the useful and effective way of financing. Only this cooperative model can let the three sides cooperate deeply, can promote the development of private colleges in the new situation, and can solve the colleges' problems of financing. Government and the publics should pay attention to education, and invest more resources to it, include funds, teaching resources and other facilities. Enterprises should play a leading role on subsidizing the colleges, and the government should act a good role of leader in the development of private education. First, the government should play a leading role in the cooperation between school and enterprise, introduce relevant policies so as to strengthen the cooperation, clear the rights and obligations of each side, and manage the relationship and the construction of organization of the two sides carefully according the principle of information disclosure. Second, after clarify the right and obligation of each side, we should manage the project of investing and financing by the two sides according to some certain specifications. Combine with the effective supervising regime during the daily management by the organization which divides the work, we should establish the special department to coordinate the relationship and strengthen the feeling of responsibility of each side, so as to solve the problems when the two sides are cooperating. Third, make the best of the supervision which comes from the publics, so as to improve the extent of open and disclosure of private education, and improve the abilities of investing and financing, finally, promote the private education makes progress.

Compare with the public universities or overseas universities, domestic private colleges in China often receive fewer social donations, to raise funds by the way of receiving social donation is the shortcoming of the colleges. Therefore, the colleges should pay more attention to social donating. Many overseas universities could receive tens of billions dollars donation every year, such as Harvard University and Cambridge University, etc, even there are some special financial institutions that specialize in the operation of the school; private colleges in China should learn this model, and then, to exploit the potentialities of social donating, or to establish the special institutions for raising funds, so as to increasing the ways of financing, improve the financing abilities of the colleges, and promote the development of the domestic private colleges.

\section{Conclusion}

To the private colleges, the issue of investment and financing is related to its future development, is related to the level of its running and its teaching quality. At present, there are many problems during the investment and financing of the private colleges, such as lack of governmental management and educational funds, ways of investment is quite few, funds from public financing are very little, moreover, the risk of investment and financing is existed all the time, these greatly block the healthy development of private colleges. In order to make a breakthrough, the private colleges must increase the way of financing, try their best in all fields, adopt the diversified investing and financing ways, so as to solve the investing and financing problems of the schools. Because of the writer's limited knowledge, there still are some shortcomings in the author's point of view on the issue of private colleges' investment and financing, welcome all the specialists and scholars to study this issue further, so as to promote the diversified investment and financing of private colleges in China.

\section{Acknowledgements}

The national education science five-year plan: Research on public-private mixed ownership in modern universities. Number: BIA160122.

Shaanxi Provincial Department of Education key scientific research projects :

Private Colleges and Universities in Shaanxi Investment and Financing


Management Mechanism Design Research and Education Foundation was created. Number: $13 J Z 074$.

\section{References}

[1]Kong ying, Liang Keyin, Annual Report of the Recent Researches and the Hot Issues on China's Private Higher Education 2007[J]. Journal of Zhejiang Shuren University(Humanities and Social Sciences), 2008,(06):18-25.

[2]Yang Deling, Chen Wanming, Explore and Analysis on the Present Investing Situation and Investing Countermeasures[J]. Journal of Henan Normal Universtiy, 2012,39(05):237-240.

[3]Wang Yuxuan, Financing Structure and Efficiency of Manage of the Higher Vocational School[D]. ShanDong University, 2010.

[4]Liu Bin, Chen Hongping, Zhang Genshui, etc, Research on Financing Countermeasures of the Higher Education in China[J]. Higher Education Development and Evaluation, 2006(12).

[5]Jin Huifang, Research on the Issue that Private Colleges Use the Capital Market to Finance Funds[D], Nanchang University, 2009.

[6]Jiang Xinyin, Research on Countermeasures of Diversified Investment and Financing of Private Education[J], JOURNAL OF JILIN TV\&RADIO UNIVERSTIY, 2014,(08):103-104.

[7]Liang Shiyun, Huang Jing, Review, Compare, and Analysis on the Pluralism of the Higher Education[J].Research on Non-Governmental Higher Education, 2006(3). 